\title{
The Legal Academy's Engagements with Lawtech: Technology Narratives and Archetypes as Drivers of Change
}

\author{
${ }^{1}$ Kate Galloway \\ Griffith University, Australia \\ Julian Webb \\ University of Melbourne, Australia \\ Francesca Bartlett \\ University of Queensland, Australia \\ John Flood \\ Griffith University, Australia \\ Lisa Webley \\ University of Birmingham, United Kingdom
}

\begin{abstract}
This article argues that legal education is currently grappling with three narratives of technology's role in either augmenting, disrupting or ending the current legal services environment. It identifies each of these narratives within features of curriculum design that respond to legal professional archetypes of how lawyers react to lawtech. In tracing how these influential narratives and associated archetypes feature in the law curriculum, the article maps the evolving intersection of lawtech, the legal profession and legal services delivery in legal education. It concludes by proffering the additional narrative of 'adaptive professionalism', which emphasises the complex and contextual nature of the legal profession, and therefore provides a more coherent direction for adaptation of the law curriculum. Through this more nuanced and grounded approach, it is suggested that law schools might equip law graduates to embrace technological developments while holding on to essential notions of ethical conduct, access to justice and the rule of law.
\end{abstract}

Keywords: Lawtech; Legal Education; Curriculum; Legal Profession; End of Lawyers; Disruption; Adaptive Professionalism; Regulation.

\section{Introduction}

As the legal profession seeks to adapt to a changing legal services environment, including the introduction of digital technologies into legal practice ('lawtech'), ${ }^{2}$ the legal education curriculum and its function have again come under the spotlight. ${ }^{3}$ Review of the accredited curriculum is part of a broader and ongoing re-examination of the purpose of legal education

\footnotetext{
${ }^{1}$ Kate Galloway, School of Law, Griffith University; Julian Webb, Melbourne Law School, University of Melbourne; Francesca Bartlett, TC Beirne School of Law, University of Queensland; John Flood, Centre for Social and Cultural Research, Griffith University; Lisa Webley, Birmingham Law School, University of Birmingham, UK.

${ }^{2}$ Corrales, "Digital Technologies."

${ }^{3}$ Law Council of Australia, "Redrafting the Academic Requirements."
}

This work is licensed under a Creative Commons Attribution 4.0 International Licence. As an open access journal, articles are free to use with proper attribution. ISSN: 2652-4074 (Online) 
(training with and for the profession, training with the profession or a broader liberal legal education) ${ }^{4}$ including consideration of the nature of the curriculum as to core knowledges and professional capacities (i.e., professional 'soft' skills). ${ }^{5}$ Within this conversation around the content of a standard qualifying law degree, lawtech has recently surfaced as a point of discussion: Should lawtech have a central role within the curriculum? Should coding be taught? Do law students instead need to be digitally literate ${ }^{6}$ or (moving beyond the technology-as-toolkit model) would it be better to focus on developing students' conceptual understanding of the larger law-technology relationship? ${ }^{7}$

While legal education is known to have a role beyond educating lawyers, it continues to be regulated by, and seeks to serve, the legal profession. ${ }^{8}$ The 'core' law curriculum in common-law jurisdictions generally, and in Australia in particular, thus remains closely tied to areas of knowledge prescribed by long-established conceptions of preparation for practice. Further entrenching the relationship between legal education and the needs of the profession, universities court relationships with employers to ensure graduate employment and, for law schools, this involves connections with law firms and large corporates as primary employers. ${ }^{9}$

As part of their employability agenda, in recent years, law schools have sought to respond to a future of work driven by emergent technologies ${ }^{10}$ by enhancing graduates' digital capabilities. ${ }^{11}$ Despite this work at the broadest level in universities, the profession itself has not clearly articulated its expectations of legal education to equip lawyers for a technology-enhanced practice. ${ }^{12}$ A number of reports by professional bodies around the (common-law) world share a fairly vague vision of the future (or present reality) of legal practice that give a nod to the need for an enhanced law curriculum ${ }^{13}$ but offer little specific direction for the academy in terms of meeting perceived needs. Similarly, despite hinting at the need to future-proof the regulatory requirements for an accredited degree, the current review of the mandated law curriculum in Australia fails to engage directly with lawtech. ${ }^{14}$ Consequently, the academy is confronted by a double void. The regulatory framework prioritises discipline content and is silent on technological literacies in legal education, and there is no clear articulation by the profession about the role and structure of legal education necessary or desirable to support the contemporary and future workforce in terms of lawtech. Law schools have thus been left to their own devices to interpret the needs of the profession and to develop the law curriculum accordingly - albeit within the long-accepted assumption in many jurisdictions that law schools are or should be the only suppliers of law education and practitioners.

Against this background, this article considers how legal education is responding to the needs of contemporary legal practice, notably in terms of equipping graduates to engage with lawtech. It builds on our earlier analysis of the predominance of a number of law and technology narratives within the discourse of the legal profession. ${ }^{15}$ In our earlier article, we identified three dominant narratives about the effect of technology on legal practice, each of which is represented by a professional archetype of the lawyer in a tech-driven world. Thus the 'True Legal Professional' represents a narrative of status professionalism, the 'Technological Disruptor' is derived from Christensen's innovators, ${ }^{16}$ and 'Death' embodies Susskind's vision of radical decomposition of the traditional professional. ${ }^{17}$ While not assuming that the current monopoly idea of professionalism as the sole supplier of future 'legal industry workers' is the only pathway to a desirable integration of legal professional skills and technologies, we focus here on the contemporary Australian law curriculum as delivered by law schools. We analyse this curriculum with reference to the core regulated subjects and case studies of curriculum innovation in lawtech to illustrate how legal education can be interpreted as a response to these three archetypes. However, echoing our earlier article, we find these accounts wanting in their ability to provide a coherent framing of the law curriculum sufficient to embrace the more complex

\footnotetext{
${ }^{4}$ See, e.g., Keyes, “Changing Legal Education”; Parker, "Failed Sociologists”; Leighton, "LLB as a Liberal Degree?”; Strevens, 'Changing Nature"; James, "More Than Merely Work-Ready"; Stone, "Women, Law School and Student Commitment."

${ }^{5}$ Godwin, "Legal Education"; Sparrow, "Teaching and Assessing"; Heath, "Learning to Feel Like a Lawyer."

${ }^{6}$ Galloway, "Rationale and Framework"; Bates, "Are "Digital Natives' Equipped."

${ }^{7}$ Webb, "Information Technology."

${ }^{8}$ Duncanson, "Legal Education"; Collier, "Liberal Law School”; James, "Why Has Vocationalism Propagated."

${ }^{9}$ See, e.g., the discussion in Barker, "Avalanche of Law Schools"; cf. Thornton, "Selling the Dream."

${ }^{10}$ Brynjolfsson, Second Machine Age; Schwab, Fourth Industrial Revolution; Susskind, Future of the Professions.

${ }^{11}$ See the examples discussed in the section titled 'Christensen: Technological Disruptor' in this article.

${ }^{12}$ The Law Society, Future of Legal Services; Chittenden, Capturing Technological Innovation; CBA Legal Futures Initiative, Futures; The Law Society of New South Wales, Future of Law; Productivity Commission, Access to Justice Arrangements.

${ }^{13}$ The Law Society of New South Wales, Future of Law.

${ }^{14}$ Law Council of Australia , "Redrafting the Academic Requirements."

${ }^{15}$ Webley, "Profession(s)' Engagements with Lawtech."

${ }^{16}$ Christensen, The Innovator's Dilemma.

${ }^{17}$ Susskind, End of Lawyers?; Susskind, Tomorrow's Lawyers; Susskind, Future of Law.
} 
and nuanced needs of the profession in the face of technology. Therefore, in the final part of this article, we make a case for adaptive professionalism as a more comprehensive conception of the legal professional and therefore of the purpose of a law curriculum that has evolved in terms of lawtech.

\section{Background: The Law Curriculum}

Curriculum remains a surprisingly fugitive concept. It is generally considered to be the subjects comprising a course of study. More generously, it may sometimes be deemed to include broader elements like the role of the learner, pedagogy and learning support systems, ${ }^{18}$ but the critical point remains that the higher education curriculum lacks the disciplinary foundation and coherence found in school education 'curriculum studies', and is left to develop in often highly localised and tacit ways. ${ }^{19}$ Barnett and Coate, for example, point out that in the UK context there is very little discussion around curriculum. ${ }^{20}$ Hicks, too, has identified a 'dearth of writing on the subject' of curriculum in Australia. ${ }^{21}$ Of note, Hicks found only one university that adopted a clearly stated definition. His observation is that curriculum is 'something partial, used atomistically, in a limited and assumed way, usually attached to some other issue.'

This tendency can be observed in contemporary policy imperatives in higher education, framed around constructs like 'learning and teaching', the 'student experience', 'employability', 'graduate attributes' and 'student learning.' While each of these terms might imply attention to curriculum, none of them engages explicitly with the idea. They require, for example, attention to principles of constructive alignment ${ }^{22}$ and to graduate employability as the core goal of undertaking a higher degree. Barnett and Coate maintain that the discourse thus generally fails to embrace the fullest potential of a course of study: that of humanistic engagement between people.

Academic discussion about the law curriculum in Australia, however, has been more wide-ranging than the work of Barnett and Coate and Hicks might suggest. In policy and regulatory terms, curricular debate in legal education has tended, historically, to have been dominated by profession- or state-led interventions focused on subject prescription and doctrinal content. This has given the 'core' of common-law legal education internationally a relatively homogeneous form, reflecting often questionable ${ }^{23}$ assumptions about the necessary building blocks of the curriculum that may owe more to the weight of history and attitudes of (conservative) incrementalism than to any epistemological necessity. ${ }^{24}$

In Australia, this can be observed in the continuing dominance in regulatory debate of the core doctrinal content of the so-called Priestley 11 subjects (or 'Priestleys'): the 11 doctrinal subjects that must be successfully completed for a law graduate to apply for admission into practice. ${ }^{25}$ The Priestleys currently comprise specified subject areas and a list of topics within each subject, ${ }^{26}$ although each subject contains an alternative catch-all provision. However, accrediting bodies in each state interpret the requirements differently. Consequently, some accrediting bodies prefer the prescriptive list, and they may require evidence of how these topics are taught or the cases used to explain particular points of doctrine. This affords a potentially restrictive remit to law schools in framing their curriculum depending on the approach adopted in their jurisdiction.

In addition to the ongoing discussion concerning the role of doctrine in curriculum, there is extensive literature about diverse aspects of the law curriculum that seek to reposition the study of law beyond doctrine. In recent decades, the legal academy has grappled with how to develop law curriculum in terms of Indigenous perspectives, the first-year experience, internationalisation, ethics and professionalism, sustainability education, critical thinking and the broader contexts of law, as

\footnotetext{
18 Fraser, "The Curriculum?'

${ }^{19}$ Fraser, "The Curriculum?'

${ }^{20}$ Barnett, Engaging the Curriculum.

${ }^{21}$ Hicks, "Curriculum in Higher Education."

22 As advocated in, e.g., Biggs, Teaching for Quality Learning.

${ }^{23}$ Cf. the late Peter Birks's persistent attacks on the narrowness and relative incoherence of the 'foundation' subjects in England and Wales, e.g., Birks, "Compulsory Subjects."

${ }^{24}$ See Webb, "Preparing for Practice," which offers a comparative review of reform trends in major common law jurisdictions since the 1990s; also Webb, "Tale of Two Cities," which considers the historical drivers of legal education reform in England.

25 See, e.g., Monahan, "Competency-Based Education."

${ }^{26}$ A revised set of 'Priestley' requirements is currently out to consultation which would see the topic lists dropped from these prescriptions. See Law Council of Australia, "Redrafting the Academic Requirements."
} 
well as skills education and work-integrated learning. ${ }^{27}$ Thus, the concept of curriculum reflected in the Priestleys - one focused on doctrinal content — is much narrower than that comprehended by the academy.

Regardless of how liberally the Priestleys are interpreted, the constraints on the law curriculum imposed by regulation remain a challenge both for the academy and the profession. ${ }^{28}$ As the literature demonstrates, it is entirely possible to orient the curriculum in several directions using the core as a doctrinal starting point. However, these innovations have occurred despite regulation, not because of it, and they are bounded by doctrinal imperatives. Further, developments in lawtech that are affecting or will affect legal practice represent a huge scope for curriculum development that is not currently contemplated within the regulated framework but must be added to the current mix. While law schools interpret the lawtech learning outcomes in their own ways, there is little guidance either from the accrediting bodies or the profession as to what needs to be learned and why.

The New South Wales Law Society's 'Future of Law and Innovation in the Profession' (FLIP) report, for example, provides a long list of essential skills for the graduate lawyer including technology, practice, business, project management, international and cross-border skills; interdisciplinary experience; and resilience and flexibility. ${ }^{29}$ The report recommended adding these skills to the curriculum, and also advocated retaining the 'black letter law areas of knowledge and lawyer skill sets.' ${ }^{30}$ It acknowledged that the challenge was to incorporate all of these skills in a 'crowded curriculum', without providing an answer as to how this could be done.

The FLIP report encapsulates the challenge for legal education, as do similar reports from other jurisdictions. ${ }^{31}$ It lacks a singular narrative about the direction of the profession in the face of lawtech, representing instead a convergence of diverse narratives. Compounding the convergence, broad sets of skills are superimposed upon the existing doctrinal structure. Consequently, the 'essential skills' listed are so underdetermined as to lack both substance and coherence in terms of framing a curriculum. The recommendations lack clarity in terms of the purpose of the curriculum save for a very diffuse notion of the future of law. A similar lack of clarity can be observed in the legal education sector. As revealed by a 2017 desktop survey of Australian law schools' websites, there has been a patchwork of curricular responses to lawtech thus far. ${ }^{32}$

One might well ask why this is a problem. While the philosophy of allowing 'a thousand flowers to bloom' has merits, certainly over narrow and unduly functionalist alternatives, it points to an apparent and continuing absence of proper debate about the place and purpose (other than the diffuse 'to equip law graduates for practice') of lawtech in the curriculum. This means that it is likely that the academy's understanding of how and why to engage with technology in curriculum will be mediated, at best, through existing legal technology narratives. ${ }^{33}$ In the following sections, we analyse the law curriculum in terms of these narratives and the lawyer archetypes derived from them. Aligned with our earlier paper, we use these narratives to assess the capacity of contemporary curriculum innovation to address the impact of lawtech in diverse legal sectors, while continuing to address the myriad imperatives of legal education.

\section{Status Professionalism-True Legal Professionals}

Despite claims by some that the Priestleys are simply a guide, or as former law dean Gillian Triggs has said, a 'surprisingly light hand' ${ }^{34}$ the rules can be interpreted - by accrediting bodies, by those overseeing their law school's curriculum or by individual teachers - as a checklist of content that must be delivered, and a mechanism for assuring the relative consistency of

\footnotetext{
${ }^{27}$ See, e.g., Burns, "Indigenous Cultural Competency"; Shircore, "From the First Year"; Galloway, "Approaches to Student Support"; Galloway, "Using Sustainability to Inform Renewal"; Lo, "Before Competition"; Kift, "21st Century Climate for Change"; Robertson, Ethics Project.

${ }^{28}$ This is exacerbated by both the expansion and internationalisation of the student cohort, in that for a significant proportion of the cohort, local admission requirements may be functionally irrelevant, because a high proportion of students may have no intention to (or realistic prospect of) practice in Australia, and/or the local requirements are in some way irrelevant or superfluous to recognition in students' home jurisdictions.

${ }^{29}$ The Law Society of New South Wales, Future of Law, 78-9.

30 The Law Society of New South Wales, Future of Law, 77.

${ }^{31}$ See, e.g., the Chartered Institute of Legal Executives in the UK, which sought to review its legal education and training schema in the light of lawtech developments, seeking to strike a balance between the needs of current practice and those that were foreseeable within the next 5-10 years. It has recently concluded that the knowledge and skills associated with lawtech should be embedded within its curriculum and assessment regime; CILEx, "Consultation"; CILEx, "Analysis of Consultation Questions."

${ }^{32}$ Galloway, Disrupted Law Degree; Perry-Petersen, "Legal Innovation."

${ }^{33}$ Webley, "Profession(s)' Engagements with Lawtech"

${ }^{34}$ Law Council of Australia, "Redrafting the Academic Requirements", 21.
} 
curricula across time and place. Consistency itself matters within a professional discourse that sees maintaining a broadly onesize-fits-all model of professional formation as a function of professional regulation even, or especially, in a market context shaped increasingly by professional segmentation and (sub)market differentiation. ${ }^{35}$ A survey of property law teaching across Australia, for example, revealed a generally consistent approach to the content and assessment. ${ }^{36}$ Consistency of approach to doctrine is also evidenced by almost any Australian law text's coverage of a core substantive law subject (and most introductory texts), which tends to be relatively predictable.

We suggest that this apparently widely understood conception of the contemporary curriculum reflects the status professionalism narrative of the law, whereby the profession 'occupie[s] a niche high in the system of social stratification. ${ }^{37}$ Thus, notwithstanding diversity in teaching method or approach, we suggest that the law curriculum is emblematic of status professionalism in three ways. The curriculum reproduces the norms adhered to and experiences of those who promote it, its content is oriented to reflect the priorities of status professionalism and it reinforces the status norms expected by the students who seek to qualify as lawyers through learning the curriculum.

First, the very fact of the Priestleys as the definitive list of highly specialised professional knowledge represents the influence of the judiciary and senior levels of the profession who originally mandated, and continue to mandate, the content. The courts retain authority over admission to practice and thus the standards for accreditation of law schools. Unlike other professions with threshold admission qualifications, the law holds constitutional power as the third arm of government, affording a unique means of commanding the reproduction of professional norms and upholding its own status.

The Priestleys are applied around the country by state-based regulators who themselves are educated in the system they enforce. They themselves are taught by academics who also come from the system and whose identity is intertwined with the doctrine they profess. ${ }^{38}$ Insofar as the rules-doctrinal curriculum content-continue to reflect traditional norms of the 'compleat lawyer' ${ }^{39}$ they are implicated in the wider discourse of status professionalism indicative of the profession more broadly. In particular, they support the traditional structures of the profession enjoyed by those in the senior ranks who themselves make the rules. Thus, through these scaffolded controls, the profession reproduces status professionalism through (largely) creating graduates who reflect their own understanding of what it is to be a lawyer, grounded in the same traditions and education.

Second, the content of the core curriculum is not merely doctrinal - it is commercially oriented. Evidencing the embrace of commercial success by status professionalism, the focus of the law curriculum's core content is framed clearly to fit mainstream practice with an emphasis on law reflecting private and corporate interests, and the processes of litigation. ${ }^{40}$ Consequently, some have observed how legal education has increasingly prioritised the market at the expense of a student focus on public interest or social justice. ${ }^{41}$

Although law schools are now introducing diverse approaches to teaching law including clinical legal education and law and technology subjects, there is little evidence that the core doctrine will willingly cede room for a reorientation of legal education to meet diverse needs beyond reproducing what has gone before. Thus, the FLIP report concluded that the core curriculum remains essential, but that law graduates simply need to know and be able to do more. ${ }^{42}$ We have previously described status professionalism as 'Janus-faced', ${ }^{43}$ whereby new technology can be classed as either reinforcing the status quo or an interloper that may disrupt the status quo. The curriculum also evidences this duality - upholding the core while promoting a raft of 'bolton' extras or warning about the dangers of rethinking traditional legal skills and knowledge. So long as lawtech remains an

\footnotetext{
${ }^{35}$ See, e.g., Francis, At the Edge of Law, seriatim; Webb, "Turf Wars", 95-6.

${ }^{36}$ Carruthers, "Teaching Property Law." A follow up survey in 2019 revealed that little has changed in terms of content; Carruthers, "Survey of Australian Property Law Teachers."

${ }^{37}$ Elliot, Sociology of the Professions, 14. See also, Webley, "The Profession(s)' Engagements with Lawtech."

${ }^{38}$ Galloway, "Guarding Our Identities", 15.

${ }^{39}$ Widgery, "The Compleat Advocate."

${ }^{40}$ At the same time, and again reflecting the need to justify its standing as an independent profession entitled to maintain a discrete market for legal services, the regulated curriculum includes the study of ethics as a field of 'content' in Australia. Ethics teaching has itself attracted critique, reflecting tensions between a doctrinal focus and a values-based or more critical approach to professionalism. See, e.g., Robertson, "Renewing a Focus on Ethics."

${ }^{41}$ Thornton, "Demise of Diversity"; Ardill, "Critique in Legal Education”; Carrigan, "They Make a Desert."

${ }^{42}$ The Law Society of New South Wales, Future of Law.

${ }^{43}$ Webley, "The Profession(s)' Engagements with Lawtech."
} 
afterthought in a predominantly content-driven doctrinal curriculum, the cost of status professionalism as a curriculum driver is likely to be a lack of coherence in graduate outcomes and an unwillingness to reform.

Finally, the target of legal education's reproduction of status professionalism is the law student. Inevitably, law students are informed about the study of law through representations in popular culture and through the prestige of law in society. ${ }^{44}$ These models are predicated upon the very privileges and rewards that are implicit within the discourse of status professionalism, which is itself replicated in both the formal and informal law curriculum. ${ }^{45}$ For a law student seeking to enter this realm, a degree program at odds with the traditional conception of the 'compleat lawyer' is not a law degree at all. To this extent, law schools face the dilemma in designing their curricula, of exactly what it is they are providing: education and training to be what the profession understands a lawyer to be? Or a more diverse model of legal services provider whose skill set is not so narrowly defined by ascribed status?

This brings us to the two other competing narratives that colour contemporary discourses around the law curriculum and the advances in curriculum offerings developed by law schools. We turn first to examine the narrative of the technological disruptor.

\section{Christensen: Technological Disruptor}

As we identified in our earlier article, Christensen's conceptualisation of business models as either sustaining or disruptive is as applicable to the legal profession as it is to any other industry. ${ }^{46}$ Although Christensen's analysis has been the subject of debate ${ }^{47}$ it provides a useful framework, particularly as the term has had widespread uptake in discussions around lawtech and the legal profession. The business orientation of disruption that has been widely adopted in discussions about the future of legal practice encompasses a technology-mediated approach to legal services ${ }^{48}$ where technology is 'the tool used to disrupt rather than the root [cause] of the disruption. ${ }^{49}$ However, this presupposes the capacity of the existing profession to adapt to new market models as a means of protecting its market share as it faces new and divergent competition-for example, through technology companies such as LegalZoom, and a variety of 'NewLaw' practice models that use process automation to reengineer service delivery and pricing.

In legal education, the disruptive innovation narrative does not seek to overthrow everything about a traditional legal education. There is a call on law schools to change structurally, notably in the way that they deliver education. The nostrums of disruptive innovation in legal education thus include calls for moving much more teaching online, and to using modern learning technologies such as modularisation, competences and learning outcomes more effectively or creatively to increase the flexibility, diversity and continuity of legal education offerings. Despite reorganisation, these proposals maintain some degree of standardisation. ${ }^{50}$ Online and modular instruction facilitates the other component of 'innovation' in legal education: developing a particular mindset. ${ }^{51}$ Central to this endeavour is the goal of reconstructing law graduates as 'poly-technical' legal entrepreneurs rather than compleat lawyers. To some extent, this builds on status professionalism's growing concern of maintaining its relevance by emphasising lawyers' 'commercial awareness', financial literacy and the ability to use data in the interests (especially) of business clients ${ }^{52}$ - but disruptive innovation demands more. A core function of legal education thus becomes exposing students to the realities of the legal industry and equipping them with the skills to participate in different organisational structures, providing new products or ways of doing things for their clients. ${ }^{53}$

\footnotetext{
${ }^{44}$ Some studies suggest that a significant number of law students embark on a law degree because of its prestige. See, e.g., Larcombe, "Law Students' Motivations." See also, Moorhead, "Ethical Identity."

${ }^{45}$ See, e.g., Kennedy, "Legal Education" for an early and well-known statement of this position.

${ }^{46}$ Webley, "The Profession(s)' Engagements with Lawtech."

${ }^{47}$ See, e.g., Weeks, "Is Disruption Theory Wearing New Clothes"; Gobble, "Defining Disruptive Innovation."

${ }^{48}$ See, e.g., The Law Society of New South Wales, Future of Law.

${ }^{49}$ Guihot, "New Technology", 405.

${ }^{50}$ Pistone, "Disrupting Law School”; Katz, "MIT School of Law?"

${ }^{51}$ Evident in reports of professional bodies such as The Law Society of New South Wales, Future of Law; Chittenden, Capturing

Technological Innovation; CBA Legal Futures Initiative, Futures.

52 The Law Society of New South Wales, Future of Law, 18, 19, 39, 40, 78, 104.

${ }^{53}$ See generally, Cooke, "New Future"; Waye, "Innovation in the Australian Legal Profession."
} 
The archetype of the law student as (disruptive) entrepreneur has been characterised by Katz as requiring law schools to embrace a 'configuration' of 'Law+Tech+Design+Delivery. ${ }^{, 54}$ We focus on three examples of curriculum innovation that appear to fit the trope of Technological Disruptor: design thinking, Law Without Walls and app (computer application) design.

\section{Design Thinking}

Implicit in the doctrinal focus of the traditional law degree is an emphasis on developing the skill of 'thinking like a lawyer.' In an increasingly competitive market for legal services, however, the professional literature has embraced additional thinking skills, including design thinking, ${ }^{55}$ as part of the lawyer's toolkit.

Design thinking is a process by which a product or service is developed with a focus on the needs of the user (client). The process, popularised by Tim Brown's best-selling book Change by Design ${ }^{56}$ is heavily practice-focused, involving hands-on stages of collaboration, ideation, testing and refinement. Brown describes design thinking as a means of embracing imagination, risk-taking, failure and cross-disciplinary involvement. These features ostensibly put it at odds with much of traditional legal method and even conventional thinking about regulatory and dispute system design. Here, there is a focus on the client, rather than the profession (as in status professionalism), as the standards setter.

Within the framing of a disrupted legal services industry, design thinking offers far more than the ability to answer a legal question. Instead, it is touted as a means of delivering an enhanced service to clients, widening access and developing disrupted services, including those mediated through technologies.

Universities' uptake of design-thinking courses, including in some law schools, ${ }^{57}$ thus offers a response to the kind of future of work described by Christensen's theory of disruption - a response that inculcates in graduates the ability to adapt legal service delivery to the imperatives of the contemporary market.

\section{Law Without Walls}

Globalisation and technology come together in the international collaboration of a number of law schools, known as Law Without Walls. The program, a type of legal hackathon based in the University of Miami, has had (at the time of writing) 26 participating law schools from around the world. ${ }^{58}$ The aim of the program is, according to its website, to:

1. Create innovations at the intersections of law/business/tech;

2. Hone 21st century professional service skills desired by clients (including innovation, cultural competency, creative problem finding and solving, leadership, business planning, communication and collaboration); and

3. Transform relationships between lawyers and clients. .9

It achieves this through a structured process reflecting the principles of design thinking. Business and law students are put into teams with a topic expert, mentor and adviser. They are given a problem and collaborate to form a solution. They are supported by external coaches, who assist with 'branding, develop[ing] their business case, deal[ing] with teaming issues, and bring[ing] their Projects of Worth to life.' The process takes place over five months, virtually and in person.

There are thus several features of the program that reflect the imperatives of a response to Christensen's Technological Disruptor. The interdisciplinary model of innovation focusing on a client's service needs and the emphasis on transforming the lawyer-client relationship situates the skillset beyond that expected in the traditional mode of lawyering. This is experiential learning in a context of business development that is, again, mediated by technologies.

\footnotetext{
${ }^{54}$ Waye, "Innovation in the Australian Legal Profession", 1459.

${ }^{55}$ As an indication of the prevalence of articles on design thinking, see Ormsby, "Award-Winning Academic"; Hambrett, "Reimagining the Delivery of Legal Services"; Perry-Petersen, "Designer's Mindset"; Ormsby, "Future in-House Lawyer."

${ }^{56}$ Brown, Change by Design.

${ }^{57}$ This is led globally by Stanford Law School, "Legal Design Lab.” In Australia, see Queensland University of Technology, "Law and Design Thinking"; Swinburne University of Technology, "LLB/Bachelor of Innovation \& Design"; and the University of Queensland's Access to Justice and Innovation Clinic (University of Queensland, "Law School").

${ }^{58}$ It should be noted that the future of Law Without Walls is currently uncertain in the absence of a continuing commitment by its primary supporter, the University of Miami, to continue underwriting the program.

${ }^{59}$ Law Without Walls, "Process + Timeline."
} 


\section{Computer Application Design}

The third example we draw on is the increasing availability of law subjects and extracurricular projects that involve the design of apps. Many of these are sponsored by the lawtech firm, Neota Logic. ${ }^{60}$ According to its website:

Neota Logic collaborates with universities to present courses in which students learn how to create software applications that 'think like lawyers' to conduct analysis, provide guidance, generate documents, and facilitate interaction between clients and lawyers. ${ }^{61}$

While there are aspects of this training that mirror Susskind's vision of the future of the profession, it also responds to the imperatives of Christensen's model of business disruption, focusing on efficiencies in legal service delivery mediated by technology. Thus, the website points out that students 'simultaneously learn traditional legal skills and how to serve the 21 stcentury needs of clients.' Students are not, therefore, leaving behind the old ways of the law. Rather, through the 'design[ing] and build[ing of] real-world applications that help the [client] organization fulfill its mission, some for internal use, others for use by the organization's own clients', the scope of their work extends beyond solving legal problems. In becoming skilled in developing systems to help clients fulfil their mission, such programs are dealing with a more technologically enabled and entrepreneurial mode of practice.

Through these three examples, we illustrate the ways in which the law curriculum is already responding to a particular account of the future of legal practice and the skills it encompasses. In these cases so far, we suggest that the existing curriculum remains relevant and core to legal education, but that it is 'enhanced' by experiential learning focused on a mindset or mode of thinking quite unlike traditional legal method. Graduate understanding of design thinking - either on its own or embedded in the actual design of technologies tailored to clients' needs - is increasingly being presented as a new capability necessary to future legal practice, and a skill set that will enable graduates to enter and achieve in a competitive technology-enabled legal services marketplace.

To that extent, law schools may be seen as mediating tensions between, and perhaps even co-constructing, the True Legal Professional and Disruptive Innovator archetypes in creating and extending the contemporary curriculum beyond the core. The products of such an education are still professionals we recognise as lawyers, but lawyers who are equipped to cope with the predicted challenges that will shake, but not replace, the profession as we know it.

\section{Susskind: Death (of the Legal Profession)}

By way of contrast with the adaptability of the Technological Disruptor to new business and new products, the Death narrative emblematic of Susskind's long-standing predictions for the future of the legal profession ${ }^{62}$ requires a radical rethinking of the law curriculum. On Susskind's analysis, technology will take over much of the existing work of lawyers. ${ }^{63}$ Nearly a decade ago, he wondered why law schools and legal academics were reluctant to inquire into a long-term view of law and legal practice ${ }^{64}$ His critique has consistently been that his observations of the reality of legal work differ markedly from 'the rarefied legal work that our law schools led us to expect (and many still do). ${ }^{65}$ By Susskind's reckoning, law schools are educating graduates for jobs that no longer exist. Calls from the profession for a host of additional graduate skills seem to support this view to an extent though, as we have seen, those calls also (arguably) fall short insofar as they continue to demand too much of the traditional knowledge base of the True Legal Professional.

Susskind's approach has been to identify alternative legal roles that demand a new mix of skills; these roles will inevitably demand a different approach to legal education. In adopting this narrative, however, legal education faces a far greater challenge than that of disruptive innovation - the more existential challenge to the very purpose of legal education summed up by the question: 'if a computer can find an answer to your natural language legal problem, how does legal education add value to our

\footnotetext{
${ }^{60}$ See, e.g., Melbourne Law School, "Law Apps"; University of New South Wales, "Designing Technology Solutions"; University of Technology Sydney, "Law School's Law Tech Challenge"; and University of Western Australia, "Legal APPtitude."

${ }^{61}$ Neota Logic, "University Programs."

${ }^{62}$ Susskind, Future of Law; Susskind, End of Lawyers?; Susskind, Tomorrow's Lawyers.

${ }^{63}$ Susskind, "Legal Informatics."

${ }^{64}$ Susskind, "Legal Informatics."

${ }^{65}$ Susskind, "Legal Informatics."
} 
students?' Discomfort at this question is likely to account for the reluctance of the academy to embrace substantive change consistent with Susskind's more radical prognostications.

There are also practical constraints. In the Australian context, law careers for non-lawyers remain emergent, leaving law schools without a ready market for graduates of radically differentiated degree programs. Higher education is not sufficiently agile to adapt quickly to market needs, and universities generally require a sound business case to implement a new degree. So long as the archetype of the True Legal Professional dominates, and until the legal services industry has clear alternative graduate roles with prospects of advancement, it is unlikely that dedicated programs will become available.

Signs of such an evolution are slowly emerging, albeit primarily at the margins, and, as we have seen, in ways that are perhaps still more consistent with the Disruptor archetype. Graduate awards in legal technology are being offered by a number of law schools internationally. ${ }^{66}$ In North America, specialist Juris Doctor subjects in quantitative legal analysis, legal analytics, legal project management and others are increasingly common. ${ }^{67}$ Strikingly too, the excessive cost and market limitations of a systemic reliance on training for status professionalism has also been recognised by regulatory initiatives permitting, for example, accreditation of new types of 'para'-professional in Ontario ${ }^{68}$ and Washington State, ${ }^{69}$ while Arizona ${ }^{70}$ and California ${ }^{71}$ are both currently exploring the removal of unauthorised practice rules that prevent legal services being delivered otherwise than by True Legal Professionals. England and Wales has sufficiently narrow unauthorised legal practice rules that it is not necessary to be an admitted legal professional to offer most forms of legal advice and assistance to the public. The lawtech sector there is thriving as a result, but questions about consumer protection necessarily arise from this.

The gap emerging between such models and the Australian system, long seen as being at the forefront of regulatory innovation in legal services, ${ }^{72}$ is striking. In a regulatory system that still seems dedicated to status professionalism, such innovations (beyond non-lawyer ownership) remain unlikely. One exception might be the approach of Victorian Legal Services Commission (the lawyer regulator), which has announced that it will be developing a 'regulatory sandbox' for development of lawtech, even by those without a professional licence. ${ }^{73} \mathrm{We}$ are yet to see whether this approach will feed through to the market and create opportunities to which law schools could respond, although the experience in England and Wales is that disruption in legal educational content remains minimal, since those who hire lawyers remain conservatively focused on what makes a 'good' day-one trainee lawyer.

Instead, Australian law deans are responding to the Death narrative of legal work in the same way they have responded to the Technological Disruptor - with ad hoc rather than systemic responses. ${ }^{74}$ Traditional law degrees are being supplemented with subjects offering the skills necessary to undertake a broader scope of legal work. Although Susskind identifies a range of skills such as legal project management, legal knowledge engineering and legal risk management, at the moment, law schools engage with this narrative principally through teaching law students to code and the establishment of technology hubs offering not only research into technologies' interactions with the practice of law, but opportunities for students to experience technology in practice.

\footnotetext{
${ }^{66}$ E.g., Master's degrees delivered by IE University (Spain; IE Law School, 'Master in Legal Tech'), Swansea (UK; Swansea University, "Legal Tech, LLM') and Tilburg (Netherlands; Tilburg University, "Law and Technology'); Graduate Certificate in Emerging Technologies and Law (RMIT, Australia; RMIT University, 'Online Graduate Certificate').

${ }^{67}$ See, e.g., Artificial Lawyer, "Legal Tech Education Guide."

${ }^{68}$ See, e.g., discussion in LETR, Setting Standards, notably paras. 6.106-8, 7.114.

${ }^{69}$ See Pistone, "Disrupting Law School."

${ }^{70}$ Goth, "Arizona Weighs Role."

71 The State Bar of California, "Options for Regulatory Reforms." Other options under consideration include removal of regulatory barriers in respect of non-lawyer ownership of law forms and restrictions on fee sharing. As mentioned in the text, these reforms have been enacted across Australia over 15 years ago. While ushering in some structural change within small law firms, the regulatory liberalisation has had little observable impact on professional stratification or general affordability of lawyers.

72 Semple, "Taxonomy of Lawyer Regulation."

${ }^{73}$ Derkley, "Regulatory "Sandbox."

${ }^{74}$ By contrast, Bond University Faculty of Law has recently announced a new Bachelor of Legal Transformation, an apparently unique degree in Australia, that seems to address the Death archetype; Neilson, "Bond University."
} 


\section{Coding for Lawyers}

The professional literature has, for some years, continued to pose the question of whether lawyers should learn how to code. ${ }^{75}$ The consensus seems to be that lawyers are best at being lawyers, while experts in coding are best placed to code. As Susskind points out, however, at the very least it is useful for lawyers to know some basic coding as a means of being able to work alongside specialists in designing lawtech.

Consequently, law schools are increasingly offering basic coding for lawyers, in particular through app-based subjects. This offers students some exposure to the means of generating technological solutions for legal problems that sideline traditional legal skills altogether. While the app-development subjects referred to above are one form of coding for lawyers, the platforms used tend to adopt a 'drag and drop' system. That is, students do not need to learn a coding language but are instead able to create the app through a simple design interface. By contrast, coding subjects proper involve some basic knowledge of at least one coding language. For example, since 2018, Melbourne Law School has offered all students a six-week course of coding, ${ }^{76}$ and Bond University's Faculty of Law offers an elective including the basics of cryptography. ${ }^{77}$

\section{Technology Hubs}

Extending the opportunities associated with a coding course, a technology hub harnesses the benefits of research into technology and law, visiting practitioners from a range of disciplines, targeted experiential learning through extracurricular activities, and networks with industry.

In Australia, the Allens Hub for Technology, Law and Innovation at the University of New South Wales, ${ }^{78}$ and the Centre for Legal Innovation in the College of Law, are prime examples. ${ }^{79}$ Both have been launched within the past two years.

Complete adoption of Susskind's narrative would likely require an alternative program altogether. Not only has there been limited uptake, but the academy's response to Susskind's narrative can also be seen in an ascendant discourse upholding the True Legal Professional by differentiating the human lawyer from the robot lawyer, emphasising the need for 'soft skills.' While this in itself demands a rethink of the traditional curriculum through a significant injection of development of students' interpersonal skills, it is a clear statement of the ongoing power of the status professionalism narrative. It also points to a (nontechnological) inverse effect of the Death archetype in legal education. In addition to the curricular developments identified here as a positive (albeit limited) response to upskilling graduates for a lawyerless technologically-mediated future, Susskind's influence has also prompted a reinvention of the True Legal Professional from a technically adept adversarial advocate to a loving and empathetic collaborator.

In both the case of the Technological Disruptor and the Death of the profession, the current mandated curriculum stands as a limitation to embracing a curriculum that properly addresses either narrative of technology-enhanced legal practice. Consequently, law schools engage in the discourse of legal futures by offering a limited number of elective subjects or extracurricular experiences. Inevitably, such an approach will be insufficient to meet the challenges of the future of legal practice anticipated by either of these conceptions.

Additionally, we observe that each narrative taken alone offers its own limitations in terms of designing a curriculum that adequately prepares legal professionals for the anticipated context of future legal practice. To navigate these challenges, we suggest instead a curriculum embracing the narrative of adaptive professionalism.

\section{Navigating a More Adequately Complex Future Curriculum-Adaptive Professionalism}

In 1904, Dewey observed that 'immediate skill may be got at the cost of power to go on growing. ${ }^{80}$ In a time when universities and professions are focused on the lifelong development of professionals, his observation remains apt. Yet in terms of the futures for the practice of law, none of the three narratives discussed here appears to provide a sufficient basis for a curriculum

\footnotetext{
75 See, e.g., recently "To Code or Not to Code"; Lee, "Establishing a Generation"; Susskind, End of Lawyers?

76 Melbourne Law School, "Coding Classes."

77 Bond University, "LAWS13-581."

78 University of New South Wales, "Allens Hub."

${ }^{79}$ College of Law, "Centre for Legal Innovation."

${ }^{80}$ Dewey, "Relation of Theory to Practice", 15.
} 
that grapples with the meaning of being a lawyer in the face of ongoing, rapid, technological change and the social and economic changes that will likely accompany it.

In sum, our analysis has shown that status professionalism remains the default driver of the curriculum. At the same time, however, law schools are also attempting to cater to both the disruption narrative and Susskind's predictions of the decomposition of law jobs. As with professional narratives more broadly, ${ }^{81}$ there is evidence that the modern law curriculum, to some extent, acknowledges features of the three narratives - not so much holistically, but rather as a spectrum of available responses to change. One way we might frame these curriculum responses to lawtech is thus to view them as (alternative or at best only somewhat complementary) strategies of thematic aggregation, segregation and immersion. ${ }^{82}$

Aggregation occurs through the addition of a separate, discrete subject, such as design thinking or coding, responding to the desired theme. It is a 'bolt-on' solution to perceived deficits in curriculum without necessarily integrating the topic within the overarching discipline or purpose of the program of study. Some law schools are now providing a series of such subjects as a focus, or 'major' within the law degree, ${ }^{83}$ providing a more coherent experience but without necessarily disturbing the core.

Segregation, such as through a hub or centre, offers deep exploration of the relevant topic, but is necessarily outside the mainstream institution of the faculty, and thus the curriculum. While faculty messaging to students may (accurately) present these organisational units as a means for students to enhance their skills, the separateness also signals the isolation of lawtech from the study of law itself.

Limited immersion experiences, such as hackathons and incubators, certainly enhance student learning in a particular area but are again discrete from the core curriculum and need not necessarily relate to the curriculum more broadly. Where the core curriculum fails to engage with lawtech, faculties deliver the mixed message of lawtech as an important skill set but not sufficiently important to be embedded within the degree program as such, and certainly not within the 'core.'

None of aggregation, segregation or immersion provide, by themselves, the solution that the future requires, and further compound the compartmentalisation of a modern law degree. The consequence of a compartmentalised curriculum, which attempts to speak to different narratives about the practice of law, is a failure to equip graduates with the underlying skills of adaptation. Thus, if legal education is seen as the bedrock for equipping legal practitioners to deal with emergent technologically-mediated contexts for legal services, then it cannot do so within its current frame: one that appears focused on narratives reflecting 'large stories' that we suggest by definition cannot capture the uncertainty and fluidity of policy around legal services and diverse regulatory and practice contexts. ${ }^{84}$ Although it is possible to integrate the technologies of legal practice into the core curriculum, the mode of regulation and the status quo of the Priestleys as (real or perceived) hallmarks of status professionalism fail to provide either the space or incentive for substantial change. As we observe in the profession more broadly, ${ }^{85}$ so too in legal education, status professionalism is grounded on a problematic assumption that a curriculum built around a core of doctrine is a self-evident good.

Yet the other competing professional narratives around lawtech, on their own, also fail to advance the capacity of legal education to provide adequately for the futures of legal practice. None on their own provide an adequately complex nor sufficiently nuanced explanation of what law graduates will become or will need to become, or how they should best achieve the (new) requisite threshold. Just as it is too early to tell whether the current shifts in the structures of legal practice will take hold, ${ }^{86}$ so too is it too early to say, for example, that coding for lawyers or design thinking really are the threshold skills that necessarily define what it is to be a lawyer in technology-driven futures. Indeed, design thinking as a skill for lawyers is backed up by limited scholarly research, and even as it has become a buzzword in the profession and to some extent in the academy, it is already being supplanted by 'systems thinking' as the emerging core professional skill. ${ }^{87}$ In this fluid context, the apparent certainty of status professionalism is, of course, appealing. Law schools can continue to focus on core professional knowledge

\footnotetext{
${ }^{81}$ Webley, "The Profession(s)' Engagements with Lawtech," in the section 'navigating a more specific future course...'

82 As described in Backer, "Parallel Tracks?"

${ }^{83}$ For example, the Queensland University of technology Bachelor of Laws includes a 'New Law, Technology, and Innovation' minor; Queensland University of Technology, "Bachelor of Laws (Honours)." The Bond University Bachelor of Laws includes a "Law, Innovation, and Technology" specialisation; Bond University, "Bachelor of Laws."

${ }^{84}$ Webley, "The Profession(s)' Engagements with Lawtech."

${ }^{85}$ Webley, "The Profession(s)' Engagements with Lawtech."

${ }^{86}$ Webley, "The Profession(s)' Engagements with Lawtech."

87 [Tjendra], "Systems Thinking"; Vassallo, Way to Design; Conway, From Design Thinking.
} 
while embracing the latest trends and challenges at the margins. Yet the danger is that such an approach understates both the scale of the challenge of technology to our thinking about law and the impact of technology-mediated practice on the very concept of professionalism itself.

One approach to these reimagined futures may be an entirely new degree program to educate for the new law jobs: contract analysts, legal knowledge engineers, resolution engineers, digital justice experts and the like. Such programs highlight the centrality of at least a cross-, or perhaps inter- or trans-, disciplinary understanding of the law-technology relation that conventional bolt-on, or even joint-honours programs, will struggle to provide. There is a risk too, however, that such approaches could sidestep the question of the need for professionals schooled in the law to safeguard citizens' rights and to promote access to justice. As we point out in our earlier article, ${ }^{88}$ Susskind makes important points about the promise of lawtech in promoting access to justice, yet a curriculum that embraces his account of the futures of legal practice risks also discarding concepts that remain useful and indeed necessary. It reduces what 'lawyers' do to a set of functional capabilities, valued primarily for their market utility. ${ }^{89}$ This may bridge some of the access gap, but at a different cost. The practices (if not the theory) of technological disruption raise large questions regarding ethics and social values. ${ }^{90}$ These arise not just in respect of the growing debates regarding privacy and technological standards, but over the extent to which disruption benefits the already privileged and further harms the vulnerable. For instance, we can connect the concerns in civil justice, around privatisation of justice, to immerging stories about failures of technologically enabled alternative dispute resolution and further concerns about unintended distortions of judicial function. There are many who also point to digital economies exacerbating precarious work and the 'uberisation' of the economy. These critical perspectives highlight the importance of understanding law in the context of both developing and maintaining a values-oriented professionalism sensitive to a technologically rich and technologically risky environment, while also critically fostering the deeper capabilities to analyse the purpose, efficacy, quality and justice of technology-driven (legal) services. ${ }^{91}$

Drawing on Dewey's comment, to support lawyers' lifelong learning, including the capacity to read their environment and to adapt through upskilling, the response to this dilemma would seem to lie in adopting a narrative of adaptive professionalism to inform curriculum design, which would enable future generations of adaptive graduates.

The premise behind such a shift in curriculum principles is not necessarily to jettison doctrine, nor to wholly reject Christensen's or Susskind's narratives. Rather, we might better regard them as subsets of a much larger transformation in our understanding of and engagement with law. Such an approach would seek to promote the learning of law in a context that sees technologyincluding but not limited to lawtech - as more than a set of functional tools. Contrary to the functional point of view, adaptive professionalism needs to start from the deep, environmental effects of information technology on society ${ }^{92}$ and the consequent epistemological necessity of viewing the law-technology relationship itself as 'intricately entangled. ${ }^{93}$

What, therefore, might an education in and for (technologically) adaptive professionalism look like?

Our starting presumption is that students must have the capacity to adapt the text and practice of the law to new and evolving circumstances within valued frameworks of professionalism as embodying commitments to ethical conduct, access to justice and the rule of law. In outline and at a bare minimum, we suggest that this requires a curriculum that engages deeply and pervasively with the transformation that technology has wrought on both law and its context. First, and central to this endeavour, is a need for a critical digital literacy: an ability to understand the basic epistemics, languages and ecologies of information. This would include recognising law as a species of information. ${ }^{94}$ Information technologies are, as Floridi observes, good at making (certain) information available, but they are less good at 'making it accessible, and even less so in making it usable.' Without these capacities, our students (as lawyers and as citizens) remain mere observers of technological transformation, rather than intelligent users and curators or ethical designers. Second, it requires scholars and scholarship engaged in a deep

\footnotetext{
88 Webley, "The Profession(s)' Engagements with Lawtech."

${ }^{89}$ For potential consequences, see Delacroix, "Computer Systems."

90 Moorhead, "Lawtech."

91 The parenthesis here makes the obvious point that these skills have value beyond lawtech, in enhancing the legal, ethical and reputational advice lawyers are able to provide technology clients and hence in repositioning lawyers as experts in technological innovation and disruption.

92 See, e.g., Floridi, Online Manifesto.

93 See, e.g., Hildebrandt, Smart Technologies, 159-85.

94 How much of this groundwork should be done pre-law or pre-higher education is moot-see, e.g., Floridi, "E-ducation."

95 Floridi, "E-ducation", 251.
} 
understanding of the changing law-technology relation, of which lawtech is simply one part. ${ }^{96}$ Technology is not merely a means of accessing and using legal information differently: it raises, for example, through techniques of architectural and techno-regulation, ${ }^{97}$ crucial questions not just about the limitations of the legal mindset, but about the form, force and future of law itself. ${ }^{98}$ Third, it follows that the challenge of technology requires lawyers' education to enable at least some critical engagement with questions of design and innovation in terms of understanding the values, material relations and social effects of law and technology on the institutional arrangements of our society.

We acknowledge this is not a small task; as Brownsword argues, ${ }^{99}$ it requires the fundamental work of reimagination regarding the nature, location and function of legal rules; the Rule of Law, to be considered more largely as a constraint on arbitrary power, however enacted through law or technological means; and the future form and focus of many areas of doctrinal law. It also requires some reimagination of work-learning practices, ecologies and regulation of lawyers and perhaps also legal service providers more broadly. ${ }^{100}$ This is work that carries with it some degree of urgency as there is much lawtech already in the wild' within the digital ecosystem. It demands an immediate change in professional practices such as regulating the profession to emerge and co-evolve rather than being retrofitted to technological adaptations (and as at present, to quash or chill such innovation). Emergent approaches, such as those of the Victorian lawyers' regulator in nurturing appropriate 'adapted' lawtech, ${ }^{101}$ are a promising sign. While many of these considerations necessarily engage with factors beyond the current model of legal education, they flag not only the need for a new narrative to drive the existing law curriculum, but also the probabilityor inevitability — of multiple and diverse forms and purposes of legal education more broadly. ${ }^{102}$ The shape and direction of these futures is beyond the scope of this article.

\section{Conclusion}

As we concluded in our earlier work, within the discourse of the legal profession, three narratives hold sway as archetypes in suggesting the futures of lawyers: True Professional, Disruptor and Death (of the profession). In this article, we contend further that the law curriculum has evolved (unevenly) in recent years in response to these archetypes. The central role of status professionalism, in particular, as embodied within the accredited core curriculum, appears to hold sway while law schools adopt various approaches to enhancing the core law curriculum in response to the other two narratives. Despite the opportunities afforded to students to embrace learning that reflects aspects of all three narratives, we conclude that none of these individually nor in partnership offers a sufficient foundation for a graduate to become an adaptive professional.

To achieve this goal requires, as we have outlined, the bare minimum of a redirection of curriculum, and therefore an academic cohort themselves constitutionally disposed to adaptive professionalism. Law academics need to build the capacity to engage in curriculum design that challenges the classificatory orthodoxy entrenched within the Priestleys. In this alternative curriculum, the text of the law might become a sandbox: a place for experimentation with diverse applications and a critical outlook that weighs up the futures of law against the benchmarks of the purpose of a diversified legal profession as an arm of the justice system. The lawyer's analytical mind is surely equipped for such processes, but so long as status professionalism has a hold over curriculum practices, developing such capacity will likely remain challenging.

The future regulation of legal education has a significant part to play. We need to change the approach to regulating the curriculum: scaling back the Priestleys seems a minimum prerequisite, but some larger redesign of the regulatory framework is desirable. Flexible and adaptive professionalism requires curriculum design that aligns with broad principles and outcomes rather than constantly (re)enacting the constraints of specific subject and doctrine. Ideally, this begs something of an evidencebased approach. We need to ask in the legal context, as Floridi asks more generally, 'what sort of abilities should we privilege

\footnotetext{
${ }^{96}$ See, e.g., Bennett Moses, "Why Have a Theory of Law"; Tranter, "Law and Technology Enterprise."

${ }^{97}$ See, variously, Tien, "Architectural Regulation"; Brownsword, "Code, Control, and Choice"; Hildebrandt, "Challenges of Ambient Law"; van den Berg, "Abort, Retry, Fail"; Brownsword, "In the Year 2061."

${ }^{98}$ See Brownsword, Law, Technology and Society.

${ }^{99}$ Brownsword, Law, Technology and Society, seriatim.

${ }^{100} \mathrm{We}$ also recognise the significant practical challenges this act of reimagination would create for the legal academy including, as one of this journal's reviewers observed, the fundamental work of building capacity to undertake and deliver the curriculum design work required. These challenges are tangential to the concerns of the present article, and sufficient to merit a paper in their own right.

${ }^{101}$ Derkley, "Regulatory Sandbox."

${ }^{102}$ Alternative models of legal education are likely to have unintended consequences such as those arising out of regulatory change in the UK. See, e.g., Webley, "Legal Professional De(Re)Regulation."
} 
and teach to tomorrow's consumers, curators, producers, and designers of information? ${ }^{103}$ These need to be abilities positioned within the context of values, that is, abilities with attributes, rather than abilities constructed as functional skills and processes.

To achieve this, given the complexity of the challenges presented by technology including lawtech, some leap of imagination is also desirable in reframing regulatory functions and relationships. As was argued in the English 'Legal Education and Training Review' (LETR), a move to a more outcomes-focused form of regulation also changes the function of the regulator to one that 'identifies the risks that need to be managed in respect of certain activities, and designates the outcomes that must be achieved in order to manage or vitiate those risks. ${ }^{104}$ Regulation itself becomes work of not just setting relatively immutable standards, but of listening, educating and curating in a way that recognises the complexity of legal education and its everevolving 'social and professional matrices.' 105 Indeed, the increasingly inter- and multi-disciplinary competences involved in creating a technologically-savvy and empowered workforce arguably strengthen the case for reconstructing regulation as a 'shared space' 106 for problem-solving, where multiple voices and strands of expertise can come together in constructive 'regulatory conversation' about the future direction of the endeavour.

It follows that none of this is to say that every law school need reproduce a singular curriculum, or to reject curriculum informed (in part) by the archetypes of the True Professional, the Disruptor or Death. Adaptive professionalism would instead open up the regulated curriculum to prioritise graduate capabilities rather than doctrinal knowledge. In this way, each law school would be free to design curricula that thoughtfully addresses those particular skills, knowledge areas or fields of practice that suit its own stakeholders and strategic direction, while mindful of the need to build the critical capabilities of the adaptive professional in a complex and evolving practice environment. Law teachers and their institutions might also prioritise building in frameworks to measure the success of their pedagogical strategies rather than falling back on untested narratives to assume good outcomes. As suggested above for the regulator as a standard setter, universities could shoulder responsibility for identifying and creating structures to test whether we achieve certain outcomes in legal education, such as courses of study truly suited to providing capabilities needed by our students for future practice. We might also assume responsibility in forming these educational aims to play a part in fostering an ethical and functional, as well as substantively just and equal, legal system. There is, at present, very limited data around educational outcomes in terms of the predisposition of law students to work in particular sectors or in certain ways, and we could build in ways to measure and reflect on this.

While redesign might result in diversity among law graduates who do not share core knowledge derived from the study of a common curriculum, a curriculum built around adaptive professionalism would instil a shared professional skill of the 'power to go on growing' and shared professional predispositions towards ethics and justice. These broad attributes seem to best meet the most fundamental of all future professional competencies.

\section{Bibliography}

Ardill, Allan. “Critique in Legal Education: Another Journey.” Legal Education Review 26, no 1 (2016): 137-160

Artificial Lawyer. "Legal Tech Education Guide.” Changing the Business of Law. Last modified 2019. https:// www.artificiallawyer.com/legal-tech-courses/

Backer, Larry Catá. "Parallel Tracks? Internationalizing the American Law School Curriculum in Light of the Principles in the Carnegie Foundation's 'Educating Lawyers'.” Comparative Perspectives on Law Justice 3 (2008): 101-70.

Barker, David. “An Avalanche of Law Schools: 1989 to 2013.” Journal of the Australasian Law Teachers Association 6, no $1 \& 2$ (2013): 1-13.

Barnett, Ronald, and Kelly Coate. Engaging the Curriculum. Maidenhead: Open Universities Press, 2004.

Bates, Daniel. “Are 'Digital Natives' Equipped to Conquer the Legal Landscape?” Legal Information Management 13, no 3 (2013): 172-78. https://doi.org/10.1017/S1472669613000418

\footnotetext{
${ }^{103}$ Floridi, "E-ducation", 251.

${ }^{104}$ LETR, Setting Standards, paras. 3.44-3.46; See also, LETR, Literature Review.

105 Maharg, "Shared Space: Regulation."

${ }^{106}$ In the LETR, this was captured in Recommendation 25 of the report, which called for the formation of a Legal Education Council and legal education lab that would support 'a community of educators, regulators, policy-makers and professionals working in provision of legal services, drawing information from other jurisdictions, other professions and other regulators to identify best practices in [legal education] and its regulation"; Maharg, "Shared Space: Regulation," para. 6.158. For further discussion and development, see also Maharg, "Shared Space and the Regulation"; Ching, "Legal Education."
} 
Bennett Moses, Lyria. "Why Have a Theory of Law and Technological Change?" Minnesota Journal of Law, Science and Technology 8, no 2 (2007): 589-606.

Biggs, John and Catherine Tang. Teaching for Quality Learning at University: What the Student Does. Maidenhead: Open University Press, 2011.

Birks, Peter. "Compulsory Subjects: Will the Seven Foundations Ever Crumble?” Web Journal of Current Legal Issues 1 (1995).

Bond University. "Bachelor of Laws Program.” Last modified 2019. https://bond.edu.au/program/bachelor-laws

. "LAWS13-581 Coding, Cybersecurity \& Cryptoliteracy for Lawyers Subjects.” Last modified 2019. https:// bond.edu.au/subject/laws13-581-coding-cybersecurity-cryptoliteracy-lawyers

Brown, Tim. Change by Design: How Design Thinking Transforms Organizations and Inspires Innovation. New York: Harper Collins, 2009.

Brownsword, Roger. "Code, Control, and Choice: Why East Is East and West Is West.” Legal Studies 25, no 1 (2005): 1-21. https://doi.org/10.1111/j.1748-121X.2005.tb00268.x

—. "In the Year 2061: From Law to Technical Management.” Law, Innovation and Technology 7, no 1 (2015): 1-51. https://doi.org/10.1080/17579961.2015.1052642

- Law, Technology and Society: Re-Imagining the Regulatory Environment. Abingdon: Routledge, 2019.

Brynjolfsson, Erik, and Andrew McAfee. The Second Machine Age: Work, Progress and Prosperity in a Time of Brilliant Technologies. New York: W.W. Norton, 2016.

Burns, Marcelle, ed. "Indigenous Cultural Competency in Law." Special issue, Legal Education Review 28, no 2 (2018).

Carrigan, Frank. "They Make a Desert and Call It Peace: The Past, Present and Future of Critical Legal Education in Australia." Legal Education Review 23, no 2 (2013): 313-44.

Carruthers, Penny, Natalie Skead and Kate Galloway. "Survey of Australian Property Law Teachers." In (unpublished) data currently held by the authors, 2019

. "Teaching Property Law in Australia in the Twenty-First Century: What We Do Now, What Should We Do in the Future?" Australian Property Law Journal 21, no 1 (2012): 57-76.

CBA Legal Futures Initiative. Futures: Transforming the Delivery of Legal Services in Canada. Ottawa: Canadian Bar Association, August 2014.

Ching, Jane, Paul Maharg, Avrom Sherr and Julian Webb. "Legal Education and Training Review: A Five-Year Retro/Prospective." The Law Teacher 52, no 4 (2018): 384-96. https://doi.org/10.1080/03069400.2018.1526472

Chittenden, Tara. Capturing Technological Innovation in Legal Services. London: The Law Society, 2017.

Christensen, Clayton M. The Innovator's Dilemma: When New Technologies Cause Great Firms to Fail. Boston: Harvard Business Review Press, 1997.

CILEx. Appendix 1: Analysis of Education Standards Consultation Questions 1-5. Bedford: Chartered Institute of Legal Executives (CILEx), March 2019.

- Consultation: On the Proposed Changes to the Education Standards Applying to Chartered Legal Executives (Fellows) and CILEx Practitioners and Related Issues. Bedford: CILEx, December 2018.

College of Law. "Centre for Legal Innovation.” About. Last modified 2019. https://www.collaw.edu.au/about/centre-for-legal -innovation

Collier, Richard. "The Liberal Law School, the Restructured University and the Paradox of Socio-Legal Studies." Modern Law Review 68, no 3 (2005): 475-94. https://doi.org/10.1111/j.1468-2230.2005.00548.x

Conway, Rowan, Jeff Masters and Jake Thorold. "From Design Thinking to Systems Change: How to Invest in Innovation for Social Impact." London: Royal Society for the Encouragement of Arts, Manufactures and Commerce-Action and Research Centre, 2017.

Cooke, Darryl. “A New Future for the Law.” Modern Legal Practice 2, no 1 (2018): 15-20.

Corrales, Marcelo, Mark Fenwick and Helena Haapio. "Digital Technologies, Legal Design and the Future of the Legal Profession." In Legal Tech, Smart Contracts and Blockchain, edited by Marcelo Corrales, Mark Fenwick and Helena Haapio, 1-15. Singapore: Springer, 2019.

Delacroix, Sylvie. “Computer Systems Fit for the Legal Profession.” Legal Ethics 21, no 2 (2018): 119-35. https://doi.org/10.1080/1460728x.2018.1551702

Derkley, Karin. "Regulatory 'Sandbox' to Encourage Legal Tech Tools.” Law Institute Journal 92, no 12 (2018). https://www.liv.asn.au/Staying-Informed/LIJ/LIJ/December-2018/Regulatory--sandbox--to-encourage-legal-tech-tools

Dewey, John. "The Relation of Theory to Practice in the Education of Teachers." In Third Year Book of the National Society for the Scientific Study of Education, Part 1, edited by C. A. McMurry, 9-30. Chicago: University of Chicago Press, 1904. 
Duncanson, Ian. "Legal Education, Social Justice and the Study of Legality." University of Tasmania Law Review 10, no 1 (1990): 16-39.

Elliot, Philip. The Sociology of the Professions. New York: Herder and Herder, 1996.

Floridi, Luciano. "E-ducation and the Languages of Information.” Philosophy and Technology 26, no 3 (2013): $247-51$. https://doi.org/10.1007/s13347-013-0124-9

- ed. The Online Manifesto: Being Human in a Hyperconnected Era. London: Springer, 2015.

Francis, Andrew. At the Edge of Law: Emergent and Divergent Models of Legal Professionalism. Abingdon: Routledge, 2016.

Fraser, Sharon P, and Agnes M. Bosanquet. “The Curriculum? That's Just a Unit Outline, Isn't It?” Studies in Higher Education 31, no 3 (2006): 269-84. https://doi.org/10.1080/03075070600680521

Galloway, Kate. Disrupted Law Degree: Australian Legal Education and Technology, 12 December 2017, https://ssrn.com $\underline{\text { labstract }=3082482}$

—. "A Rationale and Framework for Digital Literacies in Legal Education.” Legal Education Review 27 (2017): 117-42.

Galloway, Kate, Rachel Bradshaw, Neil Dunbar and Jamie Fellows. "Approaches to Student Support in the First Year of Law School." Legal Education Review 21, no 2 (2011): 235-50.

Galloway, Kate, and Peter Jones. "Guarding Our Identities: The Dilemma of Transformation in the Legal Academy." QUT Law Review 14, no 1 (2014): 15-26. https://doi.org/10.5204/qutlr.v14i1.512

Galloway, Kate, Mandy Shircore, Nichola Corbett-Jarvis and Rachel Bradshaw. "Using Sustainability to Inform Renewal of the LLB Foundation Curriculum: Knowledge Skills and Attitudes for the Future.” QUT Law Review 12, no 1 (2012): 120. https://doi.org/10.5204/qutlr.v12i1.468

Gobble, Mary Anne M. “Defining Disruptive Innovation.” Research-Technology Management 59, no 4 (2016): 66-71. https://doi.org/10.1080/08956308.2016.1185347

Godwin, Andrew, and Richard Wai-sang Wu. "Legal Education, Practice Skills, and Pathways to Admission: A Comparative Analysis of Singapore, Hong Kong, and Australia." Journal of Legal Education 66, no 2 (2016): 212-36.

Goth, Brenna, and Sam Skolnik. "Arizona Weighs Role of Non-Lawyers in Boosting Access to Justice.” Big Law Business, 16 August 2019. https://biglawbusiness.com/arizona-weighs-role-of-non-lawyers-in-boosting-access-to-justice

Guihot, Michael. "New Technology, the Death of the BigLaw Monopoly and the Evolution of the Computer Professional." North Carolina Journal of Law and Technology 20, no 3 (2019): 405-69.

Hambrett, Bruce, and Nick James. "Reimagining the Delivery of Legal Services in Australia." Lawyers Weekly, 31 May 2018. https://www.lawyersweekly.com.au/biglaw/23337-reimagining-the-delivery-of-legal-services-in-australia-the-new -lawyers

Heath, Mary, Kate Galloway, Natalie Skead, Alex Steel and Mark Israel. "Learning to Feel Like a Lawyer: Law Teachers, Sessional Teaching and Emotional Labour in Legal Education.” Griffith Law Review 26, no 3 (2017): 430-57. https://doi.org/10.1080/10383441.2017.1406791

Hicks, Owen. "Curriculum in Higher Education in Australia-Hello?” Paper presented at the 30th HERDSA Annual Conference, Adelaide, Australia.

Hildebrandt, Mireille. Smart Technologies and the End(s) of Law: Novel Entanglements of Law and Technology. Cheltenham: Edward Elgar, 2015.

Hildebrandt, Mireille, and Bert-Jaap Koops. "The Challenges of Ambient Law and Legal Protection in the Profiling Era." Modern Law Review 73, no 3 (2010): 428-60. https://doi.org/10.1111/j.1468-2230.2010.00806.x

IE Law School, "Master in Legal Tech.” Masters Programs. Last modified 2019. https://www.ie.edu/law-school/programs /masters/master-legal-tech/

James, Nickolas. "More Than Merely Work-Ready: Vocationalism Versus Professionalism in Legal Education.” University of New South Wales Law Journal 40, no 1 (2017): 186-210.

—. "Why Has Vocationalism Propagated So Successfully within Australian Law Schools?" University of Notre Dame Australia Law Review 6, no 1 (2004): 41-62.

Katz, Daniel Martin “The MIT School of Law? A Perspective on Legal Education in the 21st Century." University of Illinois Law Review, no 5 (2014): 1431-75.

Kennedy, Duncan. "Legal Education and the Reproduction of Hierarchy." Journal of Legal Education 32, no 2 (1982): 591615.

Keyes, Mary, and Richard Johnstone. “Changing Legal Education: Rhetoric, Reality, and Prospects for the Future.” Sydney Law Review 26 (2004): 537-64.

Kift, Sally. "21st Century Climate for Change: Curriculum Design for Quality Learning Engagement in Law." Legal Education. Review 18, no 1\&2 (2008): 1-30. 
Larcombe, Wendy, Ian Malkin and Pip Nicholson. "Law Students' Motivations, Expectations and Levels of Psychological Distress: Evidence of Connections." Legal Education Review 22, no 1 (2012): 71-99.

Law Council of Australia. "Redrafting the Academic Requirements for Admission." Law Admissions Consultative Committee. Last modified 2019. https://www.lawcouncil.asn.au/resources/law-admissions-consultative-committee /redrafting-the-academic-requirements-for-admission

The Law Society of England and Wales. The Future of Legal Services. London: The Law Society of England and Wales, 2016.

The Law Society of New South Wales. Future of Law and Innovation in the Profession. New South Wales: The Law Society of New South Wales, 2017.

Law Without Walls. 'Process + Timeline: How does LWOW Work?' Law Without Walls. Last modified 2019. http:// lawwithoutwalls.org/about/process_(page since removed).

Lee, Whit. "Establishing a Generation of Tech-Literate Lawyers.” Lawyers Weekly, 19 July 2018. https:// www.lawyersweekly.com.au/newlaw/23652-establishing-a-generation-of-tech-literate-lawyers

Legal Education and Training Review (LETR). Literature Review: 3. Legal Education and Conduct of Business Requirements. Legal Education and Training Review, n.d.

- Setting Standards: The Future of Legal Services Education and Training Regulation in England and Wales. Legal Education and Training Review, June 2013.

Leighton, Patricia. "The LLB as a Liberal Degree? A Re-Assessment from an Historical Perspective." International Journal of the Legal Profession 22, no 1 (2016): 87-102. https://doi.org/10.1080/09695958.2015.1119027

Lo, Vai Io. "Before Competition and Beyond Complacency: The Internationalisation of Legal Education in Australia." Legal Education Review 22, no 1 (2012): 3-50.

Maharg, Paul. "Shared Space and the Regulation of Legal Education." In New Directions for Law in Australia: Essays in Contemporary Law Reform, edited by Ron Levy, Molly Townes O"Brien, Simon Rice, Pauline Ridge and Margaret Thornton, 539-49. Canberra: ANU Press, 2017.

_. "Shared Space: Regulation, Technology and Legal Education in a Global Context." European Journal of Law and Technology 6, no 1 (2015).

Melbourne Law School. "Coding Classes.” Technology, Innovation and the Law at MLS. Last modified 2019. https:// law.unimelb.edu.au/about/technology-innovation-and-the-law/coding-classes

—. "Law Apps at Melbourne Law School." Subjects. Last modified 2019. https://law.unimelb.edu.au/students/jd lenrichment/pili/subjects/law-apps

Monahan, Geoff and Bronwyn Olliffe. "Competency-Based Education and Training for Law Students." University of Technology Sydney Law Review 14, no 3 (2001): 181-209.

Moorhead, Richard. “Lawtech: Time for a Cybernetic Legal Ethics?” Lawyer Watch (blog). 19 October 2018. https:// lawyerwatch.blog/2018/10/19/lawtech-time-for-a-cybernetic-legal-ethics/

Moorhead, Richard, Catrina Denvir, Rachel Cahill-O’Callaghan, Maryam Kouchaki and Stephen Galoob. “The Ethical Identity of Law Students.” International Journal of the Legal Profession 23, no 3 (2016): 235-75. https://doi.org/10.1080/09695958.2016.1231462

Neilson, Naomi. “Bond University New Law Degree Challenges Job Fears.” Lawyers Weekly, 9 August 2019. https:// www.lawyersweekly.com.au/careers/26253-bond-university-new-law-degree-challenges-job-fears

Neota Logic. "University Programs.” Universities \& Pro Bono Programs. Last modified 2019. https://www.neotalogic.com /pro-bono/law-schools/

Ormsby, Grace. “Award-Winning Academic Wants Law Students to Think Outside the Box.” Lawyers Weekly, 19 June 2019 , https://www.lawyersweekly.com.au/biglaw/25872-award-winning-academic-wants-law-students-to-think-outside-the-box

—. "What Does a Future in-House Lawyer Look Like?" Lawyers Weekly, 16 April 2019. https://www.lawyersweekly .com.au/corporate-counsel/25480-what-does-a-future-in-house-lawyer-look-like

Parker, Christine and Andrew Goldsmith. " 'Failed Sociologists' in the Market Place: Law Schools in Australia.” Journal of Law Society 25, no 1 (1998): 33-50. https://doi.org/10.1111/1467-6478.00078

Perry-Petersen, Andrea. “Could a Designer's Mindset Bridge the Justice Gap?” Lawyers Weekly, 15 August 2018. https:// www.lawyersweekly.com.au/opinion/23826-could-a-designer-s-mindset-bridge-the-justice-gap

Perry-Petersen, Andrea, and Michael Lacey. Legal Innovation: Education in Australian Law Schools. Self-published, September 2018. http://www.andreaperrypetersen.com.au/wp-content/uploads/2018/09/Legal-Innovation-Education-Sep -2018.pdf

Pistone, Michele R, and Michael B. Horn. Disrupting Law School: How Disruptive Innovation Will Revolutionize the Legal World. Christensen Institute, 2016. 
Productivity Commission. Access to Justice Arrangements: Productivity Commission Inquiry Report (Inquiry Report No. 72). 2 vols. Canberra: Commonwealth of Australia, 2014.

Queensland University of Technology. "Bachelor of Laws (Honours).” Courses. Last modified 2019. https://www.qut.edu.au /courses/bachelor-of-laws-honours

—_. "Law and Design Thinking." Last modified 2019. https://www.qut.edu.au/study/unit?unitCode=LLB251

RMIT University. "Online Graduate Certificate in Emerging Technologies and Law." Study with Us. Last modified 2019. https://www.rmit.edu.au/study-with-us/levels-of-study/online/online-graduate-certificate-in-emerging-technologies-and -law

Robertson, Michael. "Renewing a Focus on Ethics in Legal Education." Paper presented at the Australian Lawyers and Social Change Conference, Canberra, Australia 2004.

Robertson, Michael, Lillian Corbin, Kieran Tranter and Francesca Bartlett, eds. The Ethics Project in Legal Education. Abingdon: Routledge, 2011.

Schwab, Klaus. The Fourth Industrial Revolution. New York: Crown Business, 2017.

Semple, Noel, Russell G. Pearce and Renee Newman Knake. “A Taxonomy of Lawyer Regulation: How Contrasting Theories of Regulation Explain the Divergent Regulatory Regimes in Australia, England and Wales, and North America." Legal Ethics 16, no 2 (2013): 258-83. https://doi.org/10.5235/1460728X.16.2.258

Shircore, Mandy, Kate Galloway, Nichola Corbett-Jarvis and Ryan Daniel. "From the First Year to the Final Year Experience: Embedding Reflection for Work Integrated Learning in a Holistic Curriculum Framework. A Practice Report." International Journal of the First Year in Higher Education 4, no 1 (2013): 125-33. https://doi.org/10.5204/intjfyhe.v4i1.158

Sparrow, Sophie M. "Teaching and Assessing Soft Skills.” Journal of Legal Education 67, no 2 (2017): 553-75.

Stanford Law School. "Legal Design Lab.” Organizations. Last modified 2019. https://law.stanford.edu/organizations/pages /legal-design-lab/

The State Bar of California. "Options for Regulatory Reforms to Promote Access to Justice.” 2019 Public Comment. Last modified 23 September 2019. http://www.calbar.ca.gov/About-Us/Our-Mission/Protecting-the-Public/Public-Comment /Public-Comment-Archives/2019-Public-Comment/Options-for-Regulatory-Reforms-to-Promote-Access-to-Justice

Stone, Adrienne. "Women, Law School and Student Commitment to the Public Interest." In Educating for Justice: Social Values and Legal Education, edited by Jeremy Cooper and Louise C. Trubek, 56-87. Abingdon: Routledge, 2018.

Strevens, Caroline. "The Changing Nature of the Legal Services Market and the Implications for the Qualifying Law Degree." Web Journal of Current Legal Issues, no 1 (2011): 1-12.

Susskind, Richard. The End of Lawyers? Rethinking the Nature of Legal Services. Oxford: Oxford University Press, 2008.

- The Future of Law: Facing the Challenges of Information Technology. Oxford: Clarendon Press, 1996.

"Legal Informatics: A Personal Appraisal of Context and Progress." European Journal of Law and Technology 1, no 1 (2010): 119-45.

- Tomorrow's Lawyers: An Introduction to Your Future. $2^{\text {nd }}$ ed. Oxford: Oxford University Press, 2017.

Susskind, Richard, and Daniel Susskind. The Future of the Professions: How Technology Will Transform the Work of Human Experts. Oxford: Oxford University Press, 2015.

Swansea University. “Legal Tech, LLM.” Postgraduate. Last modified 2019. https://www.swansea.ac.uk/postgraduate/taught llaw/llmlegaltech/

Swinburne University of Technology. "LLB/Bachelor of Innovation \& Design at Swinburne Law School.” Study. Last modified 2019. https://www.swinburne.edu.au/study/course/bachelor-of-laws-bachelor-of-innovation-and-design/

Thornton, Margaret. "The Demise of Diversity in Legal Education: Globalisation and the New Knowledge Economy." International Journal of the Legal Profession 8, no 1 (2001): 37-56. https://doi.org/10.1080/09695950120103172

Thornton, Margaret, and Lucinda Shannon. "Selling the Dream: Law School Branding and the Illusion of Choice.” In Through a Glass Darkly: The Social Sciences Look at the Neoliberal University, edited by Margaret Thornton, 157-76. Canberra: ANU Press, 2014.

Tien, Lee. "Architectural Regulation and the Evolution of Social Norms." Yale Journal of Law and Technology 7, no 1 (2004): 1-23.

Tilburg University, “Law and Technology (LLM).” Masters Programs. Last modified 2019. https:// www.tilburguniversity.edu/education/masters-programmes/law-and-technology

Tjendra, Jeffrey. "Systems Thinking Is the New Design Thinking.” Business Innovation Design (blog), 25 April 2018. http:// businessinnovation.design/blog/2018/4/25/systems-thinking-is-the-new-design-thinking

To Code or Not to Code: Should Lawyers Learn to Code? Lawtomated, 30 July 2019. https://lawtomated.com/to-code-or-not -to-code-should-lawyers-learn-to-code-3-2/ 
Tranter, Kieran. "The Law and Technology Enterprise: Uncovering the Template to Legal Scholarship on Technology.” Law, Innovation and Technology 3, no 1 (2011): 31-83. https://doi.org/10.5235/175799611796399830

University of New South Wales. "The Allens Hub for Technology, Law and Innovation.” About Us. Last modified 2019. https://www.allenshub.unsw.edu.au/

. "Designing Technology Solutions for Justice at UNSW Law School.” News. 28 October 2018. https:// www.law.unsw.edu.au/news/unsw-law-students-design-apps-provide-greater-access-justice

University of Queensland, "Law School Unlocks the Benefits of Digitalisation for Marginalised People." TC Beirne School of Law News. 19 June 2017. https://law.uq.edu.au/article/2017/06/law-school-unlocks-benefits-digitalisation -marginalised-people

University of Technology Sydney. "Law School’s Law Tech Challenge for Social Justice.” Information. Last modified 2019. https://www.uts.edu.au/current-students/current-students-information-faculty-law/brennan-justice-and-leadership-program $\underline{-5}$

University of Western Australia, “Legal APPtitude.” Handbooks. Last modified 2019. https://handbooks.uwa.edu.au /unitdetails?code=LAWS5188

van den Berg, Bibi, and Ronald E. Leenes. “Abort, Retry, Fail: Scoping Techno-Regulation and Other Techno-Effects.” In Human Law and Computer Law: Comparative Perspectives, edited by Mireille Hildebrandt and Jeanne Gaakeer, 67-87. Dordrecht: Springer, 2013.

Vassallo, Steve. The Way to Design. Palo Alto: Foundation Capital, 2017.

Waye, Vicki, Martie-Louise Verreynne and Jane Knowler. "Innovation in the Australian Legal Profession." International Journal of the Legal Profession 25, no 2 (2018): 213-42. https://doi.org/10.1080/09695958.2017.1359614

Webb, Julian. "Information Technology and the Future of Legal Education: A Provocation." Griffith Journal of Law Human Dignity 6, no 3 (2019): 72-104.

Webb, Julian. "Preparing for Practice in the 21st Century: The Role of Legal Education and Its Regulation." In Jahrbuch Der Rechtsdidaktik 2017/Yearbook of Legal Education, edited by Bernhard Bergmans, 12-50. Berlin: Berliner WissenschaftsVerlag, 2018.

Webb, Julian. “A Tale of Two Cities: Reflecting on Lord Neuberger's 'Reforming Legal Education' .” In Perspectives on Legal Education: Contemporary Responses to the Lord Upjohn Lectures, edited by Chris Ashford, Nigel Duncan and Jessica Guth. Abingdon: Routledge, 2015.

Webb, Julian. "Turf Wars and Market Control: Competition and Complexity in the Market for Legal Services." International Journal of the Legal Profession 11, no 1-2 (2004): 81-102. https://doi.org/10.1080/0969595042000317451

Webley, Lisa. "Legal Professional De(Re)Regulation, Equality, and Inclusion, and the Contested Space of Professionalism within the Legal Market in England and Wales." Fordham Law Review 83, no 5 (2015): 2349-67.

Webley, Lisa, John Flood, Julian Webb, Francesca Bartlett, Kate Galloway and Kieran Tranter. 'The Profession(s)' Engagements with Lawtech: Narratives and Archetypes of Future Law.” Law, Technology and Humans 1, no 1 (2019): 626. https://doi.org/10.5204/lthj.v1.i1.1314

Weeks, Michael R. "Is Disruption Theory Wearing New Clothes or Just Naked? Analyzing Recent Critiques of Disruptive Innovation Theory." Innovation 17, no 4 (2015): 417-28. https://doi.org/10.1080/14479338.2015.1061896

Widgery, John Passmore. “The Compleat Advocate.” Fordham Law Review 43, no 6 (1974): 909-22. 